May 2014

\title{
The Political Economy of Adjustment and Rebalancing
}

\author{
Jeffry Frieden \\ Department of Government \\ Harvard University
}

This essay is based on an address to the JIMF-USC Conference on Financial Adjustment in the Aftermath of the Global Crisis, Los Angeles, April 18-19, 2014.

The author thanks Joshua Aizenman, Lawrence Broz, Menzie Chinn, Dani Rodrik, Kenneth Rogoff, Francesco Trebbi, and Stefanie Walter for very helpful comments and suggestions. 
The world's recovery from the Global Financial Crisis (GFC) was extraordinarily slow and difficult. In the United States, it took some fifty months for employment to return to pre-crisis levels. This contrasts dramatically with the norm in American recessions: since the 1930s, employment has on average taken about ten months to return to pre-recession levels. ${ }^{1}$ Output, similarly, regained its pre-crisis levels far more slowly than in other post-Depression recessions. And five years after the crisis began, median household income was still over 8 percent below its pre-crisis level. ${ }^{2}$ Recovery in Europe was even slower and more difficult. The region fell into a second recession soon after the first one ended; unemployment soared in many countries, and has remained extremely high for a very long time.

The painful recovery was due in part to the severity of the crisis itself. The Global Financial Crisis was, after all, the longest downturn since the 1940s, and the steepest

${ }^{1}$ Employment reached pre-recession levels in May 2014. For previous experiences, see http://www.pewresearch.org/fact-tank/2013/09/25/at-42-months-and-counting-currentjob-recovery-is-slowest-since-truman-was-president/ accessed May 16, 2014 ${ }^{2}$ http://www.pewresearch.org/fact-tank/2013/09/18/four-takeaways-from-tuesdayscensus-income-and-poverty-release/ accessed May 16, 2014. For useful data and graphics on these and related comparisons see http://www.minneapolisfed.org/publications papers/studies/recession perspective/ind ex.cfm accessed May 16, 2014. 
downturn since the Great Depression. ${ }^{3}$ But the principal reason for the different experience in the aftermath of this crisis was that this was not a typical cyclical recession, such as developed economies have experienced periodically for hundreds of years. It was, instead, a debt crisis - in fact, a series of inter-related debt crises. We are familiar with debt crises, of course, as they have afflicted developing economies and emerging markets on a regular basis since the 1820s. But the GFC was the first debt crisis in a rich country in decades, at least since Germany in the 1930s. And it was the first debt crisis in history to hit a whole host of rich countries at once.

Debt crises are different from garden-variety recessions, and recovery from them is much more troubled; this much has been extensively documented, especially and most recently by Carmen Reinhart and Ken Rogoff (2009). The differences are both economic and political. Economically, debt crises leave the affected societies with a debt overhang that exercises a serious drag on the economy. Both creditors and debtors focus on restoring their damaged balance sheets rather than on lending and spending, respectively. This much is well-known, and helps explain why recovery from the average debt crisis takes, according to Reinhart and Rogoff, on the order of five to seven years rather than a few months (Reinhart and Rogoff 2014).

But the intractability of debt crises is not only economic, for every debt crisis leads to political conflicts. These conflicts impede recovery both in and of themselves,

${ }^{3}$ http://www.nber.org/cycles/cyclesmain.html, accessed May 16, 2014 
and their continuation impedes the ability of policymakers to address the crisis. As an example, a quick look at a recent Reinhart-Rogoff listing of the 30 most serious systemic (national) banking crises since 1857 (not including the GFC) indicates that at least half of them were associated with major political upheavals: revolutions, civil wars, the collapse of democracy into authoritarianism or vice versa. ${ }^{4}$ Recent work by Mian, Sufi, and Trebbi shows empirically that financial crises are associated with increased political polarization (Mian, Sufi, and Trebbi 2014a). Causation is never obvious - did the severity of the crisis cause political turmoil or did the political turmoil make the crisis more severe? - and probably the arrows point in both directions. Nonetheless, the connection between debt crises and political unrest is clear.

Debt crises typically dissolve into political conflicts over how the burden of adjustment will be distributed. Conflict erupts on two dimensions. Internationally, creditor countries face off against debtor countries over the division of the costs of cleaning up bad debts. Domestically, both within debtor countries and within creditor countries, groups struggle over who will be asked to make the sacrifices necessary to resolve the debt problem. These international and domestic political struggles seriously constrain attempts to arrive at productive and constructive policies that might facilitate a more rapid recovery.

${ }^{4}$ Reinhart and Rogoff 2014, Table 1. 
In what follows, I analyze the domestic and international politics of economic adjustment to a debt crisis. These regularities also apply to related balance of payments crises, and to current discussions over "rebalancing," which have to do with the international dimension of adjustment. First, I suggest and analyze the kinds of socioeconomic and political divisions we can expect to emerge in the battles over economic adjustment, as well as the factors that help determine who will emerge victorious from these battles. Then I discuss why it is that the political conflicts often become so bitter and protracted that they impede a sensible resolution to the crisis. I start with international conflicts over adjustment, then move on to domestic political battles. In much of what follows, I elide adjustment by debtor and deficit countries; although there are differences between the two categories, they are close enough to warrant being lumped together for ease of exposition.

\section{The international political economy of adjustment}

In debt conflicts among countries, the interests at stake are clear: creditors want to be repaid, and debtors want relief. In the case of balance of payments adjustment, the analogous issue is whether the principal adjustments will be undertaken by deficit countries or surplus countries. Deficit-country adjustment typically involves imposing austerity to reduce consumption and increase exports; for surplus countries adjustment requires increasing consumption and imports. Since the GFC began there has been analogous attention to whether, and how, countries will "rebalance," that is, act to 
avoid a recurrence of the very large current account surpluses and deficits that played a central role in the crisis (Frieden, Pettis, Rodrik, and Zedillo 2012).

Standard macroeconomic analysis points to the asymmetry of the adjustment process, favoring surplus over deficit countries (and creditors over debtors). Deficit countries are under substantial pressure to adjust, especially if they find it expensive, difficult, or impossible to borrow to finance their deficits. In the limiting case of a "sudden stop" in foreign lending, the deficit country must adjust more or less immediately. Surplus countries are under no such inherent pressure to adjust.

But this asymmetry is purely economic, and debtor and deficit nations usually react to it with political efforts to redress the imbalance. For debtors have powerful weapons in their arsenal, in particular the threat of suspending service on their debts of defaulting. Creditors can threaten to cut borrowers off from financing, but debtors can threaten to cut creditors off from their earnings.

Creditors and debtors are thus drawn into explicit or implicit negotiations, in which each side has powerful weapons and powerful incentives to use them to obtain a favorable outcome. Standard bargaining approaches point out that effective bargaining power is largely a function of how attractive is each protagonist's exit option. The party better able to make a credible commitment to find an alternative to the debtor-creditor relationship in which it finds itself is better able to drive a hard bargain with the other. A related factor is the relative patience of the bargainers, with the more patient of them 
having an advantage (as in a typical divide-the-dollar game such as pioneered by Rubenstein 1982). This is linked to the existence of an exit option, to the extent that the option allows the party to be patient; in debt negotiations patience might be regarded as a function of the financial reserves at the disposal of each party.

This dynamic can be seen in a wide variety of historical settings. In the 1930s, as the world economy crumbled, virtually every debtor country defaulted on its debts, and eventually received very favorable terms from creditors. The threat to default was eminently credible, for the international financial system had collapsed and the threat of being frozen out of it was entirely empty. "Exiting" from effectively non-existent international financial markets was not very costly to debtors, while foregoing debt service payments was very costly to creditors. The debtors held virtually all the bargaining power. ${ }^{5}$

The Depression-era bargaining relationship contrasts with the situation in the early 1980s. In this episode, international financial markets remained vibrant despite serious debt problems in the developing world. Developing countries were reluctant to risk losing access to external financing, and found themselves in a much weaker bargaining position. While many did default, they were usually only able to restructure

\footnotetext{
${ }^{5}$ Two classic studies of the period, which include discussion of debt and adjustment, are Eichengreen 1992 and Simmons 1994.
} 
their debts after a long delay and at great cost. The creditors, on the other hand, were typically able to emerge from the debt crisis without too much damage. ${ }^{6}$

Prominent historical examples of bargaining over balance of payments adjustment also help illustrate the point. In the late 1960s and early 1970s, the United States was at the center of a fixed-rate monetary order, and its monetary policy was out of step with that of its partners. For several years threats and promises went back and forth, with the major European nations attempting to get the Nixon Administration to undertake the adjustment measures necessary to restore balance to American payments. In this case, however, asymmetry or no, the deficit country had most of the bargaining power: the United States had a readily available alternative, which was to destroy the Bretton Woods fixed-rate system rather than adjust to its requirements. And this is exactly what it did, showing how a deficit country could force adjustment costs onto the rest of the world if it were powerful enough.

Twenty years later, the members of another fixed-rate system were in similar disagreement. In 1991 Germany was the anchor of the European Monetary System. In the aftermath of German unification, with Germany running a current account deficit, the Bundesbank adopted a highly restrictive monetary policy that drove much of the rest of Europe into recession. Again, the monetary policy of an anchor-currency country

${ }^{6}$ Cline 1995 provides a summary of the process; see also Sturzenegger and Zettelmeyer 2006. 
was at odds with the preferences of its partners, as Germany attempted to shift some of the adjustment costs onto its neighbors; again the partners were vocal in their disagreement with German policy. This time, however, the other EMS members had an alternative available: they could violate their commitments to the EMS and let their currencies depreciate, which many of them did. In each case, the anchor-currency country had substantial bargaining power, but in the EMS case so too did other countries, so that the outcome after 1991 was more of a compromise.

In the context of the European component of the GFC, similar battles have been underway among the member states of the Eurozone. Creditors in Northern Europe want their loans to be serviced; debtors on the periphery, inside or outside the Eurozone, want their debts to be restructured. With the exception of Greece, which was in such dire straits that there was no hope of anything like full recovery, there has been no debt relief. This is quite unusual, and quite remarkable given the circumstances. It is almost certainly due to the nature of the bargaining problem. Spain and other peripheral debtors had few alternatives available to them, unless they wanted to exit the Eurozone (and perhaps the European Union), while Germany and the other Northern European creditors were in no hurry to address the debt problem. With bargaining power heavily weighted toward the creditors, the Eurozone crisis so far seems to have been managed in ways that were extremely favorable to them. 
The resolution of debt and balance of payments adjustment problems at the international level is highly political. This is certainly true of "rebalancing," the current variant of attempts to address global payments imbalances seen as dangerous. One of the more politically contentious aspects of rebalancing has been the fate of China's large current account surplus. The United States, in particular, has insisted that it is largely the job of the Chinese to reduce this surplus - by allowing the renminbi to appreciate, increasing domestic consumption, or other means. China, on the other hand, insists that the United States has a responsibility to pursue more sustainable patterns of consumption and production. In this case, again, asymmetry or no, most of the bargaining power would appear to be with the deficit country, and most of the adjustment has been undertaken by the Chinese.

A second contentious instance of conflicts over rebalancing is within the Eurozone, already alluded to in the context of intra-EU debt problems. Here, as with debts, the surplus countries have seemed to be largely in control, and most of what adjustment has taken place has been in the deficit and debtor countries. This is especially evident in the case of nations on the European periphery that were not members of the Eurozone but had hard pegs with the euro. While such Eurozone members as Spain and Portugal could appeal to their Eurozone partners for support in the interests of Eurozone stability, such countries as Latvia and Estonia had no such negotiating leverage. The former have adjusted, true, but at a much slower and less 
painful rate than the latter. This undoubtedly has much to do with the relative ability of the two sorts of deficit countries to bargain effectively with the creditor states. The interests in play are clear, and the bargaining power of the various sides seems to explain much of the outcome we observe.

I leave aside for now one important, related, aspect of this problem, which is why it often seems difficult for the parties to arrive at a deal that would be mutually beneficial. After all, even the most nakedly self-interested creditor would rather find a way to permit debtors to service their debts, even in part, than to lose everything to default. Yet it often seems that protracted bargaining makes the problem worse, and that arrangements that would make both parties better off are not arrived at. Some might argue that current trends in Europe resemble this. Inasmuch as German growth depends on the country's commercial and financial relations with the European periphery (both in and outside the Eurozone), it might be in the interest of Germany to oversee enough debt relief to allow the heavily indebted countries to start growing again, at which point they would be more attractive markets for German goods and sites for German investments. This problem - of the difficulty for countries to arrive at negotiated settlements that are advantageous to all - is important, and I return to it below. First, I discuss the domestic political economy of adjustment, which is substantially more complicated than that at the international level.

\section{The domestic political economy of adjustment}


Domestic politics is ever-present in the adjustment process, even at the international level, for governments attempting to address international adjustment problems are answerable to domestic political constituents. ${ }^{7}$ This can be an important constraint on the international politics of adjustment. Indeed, many of the more spectacular instances of political conflict over debt and balance of payments adjustment are more or less purely domestic, as the experiences of East Asia in 1997-1998, Argentina in 2000-2001, and many others demonstrate. How, then, can we think about the domestic political economy of adjustment?

We start by outlining the battle lines we expect to see in domestic political struggles over adjustment to a foreign debt burden, or to a serious balance of payments crisis. This is perhaps most simply addressed by reviewing the macroeconomic impact of such adjustment.

A country experiencing a substantial capital inflow - in the run-up to a debt or payments crisis - is thereby able to consume more than it produces, invest more than it saves, and/or import more than it exports; its government can, if it does some of the borrowing, spend more than it takes in. Once borrowing becomes difficult or impossible and the adjustment process begins, all of these relationships have to reverse: the country needs to produce more than it consumes, save more than it invests, and

${ }^{7}$ The literature on the political economy of adjustment (and reform) is enormous. A recent survey is Pepinsky 2014. 
export more than it imports, and a debtor government needs to take in more than it spends in (non-debt service) expenditures. To understand the distributional implications of these trends, it is instructive to consider the associated relative price effects, for socio-economic actors are expected to respond to changes in relative prices that affect them rather than abstract terms in national income accounting.

The relevant relative price movements necessary to the adjustment process in a debtor or deficit country are straightforward, but hardly easy. They can be simplified for the sake of illustration and clarity. In order to compress consumption and increase production, real wages and incomes need to decline. In order to increase savings and reduce investment, real interest rates must rise. To increase exports and reduce imports, the currency has to depreciate in real terms. And for the government to service its debts, it needs to increase taxes or reduce non-debt-service spending, or both. None of these measures is likely to be popular, but some groups are likely to be harder hit by each of them than others (and some may be helped).

Attempts to increase revenue and reduce spending hurt taxpayers and beneficiaries of government programs. A depreciating currency is good for exporters and import competers, but harms consumers by reducing their real purchasing power. Of great political importance is the fact that depreciation can be disastrous for households or firms with substantial debts denominated in foreign currency (Walter 2008). Higher real interest rates harm debtors but help savers. And the compression of 
real wages and incomes, of course, hurts workers and consumers directly while it helps employers. These expectations help us understand who would expect to be on the barricades - and on which side - in political battles over adjustment.

The central issue in contention in the domestic political economy of adjustment, as at the international level, is who will bear the principal burden of adjustment. One set of choices, relevant to discussion of the Eurozone crisis and that of countries on the European periphery, is between what has come to be called "external devaluation" and "internal devaluation." The former is simply a nominal devaluation of the currency, changing the exchange rate to help encourage adjustment. As above, this is particularly threatening to households and firms with foreign-currency liabilities but helps exporters and import-competers; it was the approach taken by Poland in the aftermath of the GFC. What Europeans have taken to calling an "internal devaluation" is simply domestic adjustment while keeping the nominal exchange rate fixed, typically by austerity measures to put downward pressure on wages and prices. This places the principal burden on workers, and can threaten the competitive position of tradables producers as wages and prices adjust slowly, but it protects those with foreign-currency obligations and also sustains a fixed exchange rate that may be favored by economic actors with important cross-border economic ties. ${ }^{8}$

\footnotetext{
${ }^{8}$ Walter 2013 provides an excellent and complete analysis of the choice, with an application to the process in Central and Eastern Europe in chapter 7.
} 
Other choices in the adjustment process are equally contentious, as whatever path is chosen is sure to ignite opposition from some group or other. In the aftermath of the GFC, Spain was riven over whether sacrifices would be made by taxpayers, beneficiaries of government programs, financial institutions, or others. In the United States, there was substantial controversy over the response to the mortgage debt crisis. Policy could have concentrated on relieving indebted homeowners or bailing out troubled financial institutions; in the event, virtually all efforts went to the financial institutions, and almost nothing to homeowners. ${ }^{9}$ Meanwhile, battles over fiscal policy pitted taxpayers against beneficiaries, while conflicts over monetary policy saw divisions between heavily indebted homeowners who appreciated near-zero interest rates, on the one hand, and savers - especially retirees - who had come to rely on interest income.

While divisions within debtor societies receive the most attention - everyone understands that austerity is unpopular - creditor or surplus societies can also be divided by conflicts. When the issue is how to deal with outstanding debts of a creditor nation, the most directly relevant conflict has to do with whether the creditors will give up something in order to restructure debts. And this issue could easily divide creditorcountry financial institutions from creditor-country taxpayers who resist paying for the

\footnotetext{
${ }^{9}$ Mian, Sufi, and Trebbi 2010 explore the special-interest pressures that contributed to this outcome.
} 
bad decisions of their banks. This is especially the case where debt restructuring may be better for the society as a whole, for example by restoring health to an important export market, while it imposes important costs on the creditor financial institutions themselves.

Many of the Northern European creditor nations in the Eurozone debt crisis have been torn by debates over whether, and to what extent, to force the creditor institutions themselves to shoulder some of the burden of adjustment, rather than putting in on creditor-country taxpayers or debtor-country citizens. In the run-up to the Eurozone sovereign debt crisis, in fact, many Northern European financial institutions loaded up on debt to peripheral borrowers, including sovereigns, in the expectation of a bail-out. And, in fact, the bail-out was forthcoming, at the expense of Northern taxpayers: Northern European banks received government bail-outs worth nearly 2.3 trillion euro in the aftermath of the crisis (Ewing 2013).

The European experience also demonstrates that the "public diplomacy" of a crisis response can have a powerful impact on its politics. The emergency operations put together by member states of the European Union were often presented, especially in Germany, as the result of irresponsible borrowing by profligate Southern European governments and their lazy citizens. In fact, in most of the troubled peripheral nations, loans had been made predominantly to the private sector and the rescue programs largely benefited the Northern European banks that had been just as irresponsible in 
their lending as the borrowers were in their borrowing. The rescues were as much about bailing out Northern European banks as they were about supporting peripheral European governments, but few Northern Europeans would have known that - a fact that undoubtedly colored public opinion on the matter. If German citizens had been clearer about the true beneficiaries of the bail-outs, they might have been more favorably inclined to policies to require German financial institutions to restructure intra-European debts and pay some of the price themselves, rather than shunting it onto taxpayers. ${ }^{10}$

A similar dynamic to that present in debtor-creditor conflicts can be seen in debates over "rebalancing," as countries in surplus come under pressure to reduce their surpluses by reorienting economic activity. In such export-led economies as Germany, Japan, and China, this involves directing resources away from the export sector and into domestic economic activity for domestic consumption. This almost certainly means that previously favored sectors - such as export-oriented manufacturers - will lose some of their previous favors. The economic importance of the export sector in such societies is usually mirrored by its political influence, which is likely to make it extremely difficult to point the economy in a new direction without giving rise to howls of protest.

\footnotetext{
${ }^{10}$ Rodrik 2014 makes a cogent statement of the more general point that "narratives" matter in the political process.
} 
The task of analytical political economy in these circumstances starts with tracking the expected divisions in society, and how they are reflected in the political arena. I have attempted to provide a general sense of how to think about a map of the actors in play, of how their interests translate into their policy preferences, and of how this affects the politics of adjustment. In this context, the impact of adjustment policies on relative prices, hence on the economic interests of groups in society, gives us a first cut into the kinds of political divisions to expect. Of course, governments have choices about the kinds of policies to pursue in order to adjust, and these policies are likely to reflect the relative political influence of the groups expected to be affected by various approaches. However, simply knowing the likely political cleavages tells us little or nothing about who will prevail in the political process. For this we can turn to some of the same features of bargaining models that were relevant to international negotiations over adjustment and rebalancing.

Bargaining power in domestic politics, as internationally, is in large part a function of the existence of exit options. Groups or individuals that have more readily accessible, or more credible, alternatives to current circumstances are better able to insist on more favorable terms in negotiations over adjustment. A firm that can easily pick up shop rather than pay higher taxes is in a much stronger bargaining position than one with substantial fixed assets that cannot easily be redeployed. Citizens who 
can move easily elsewhere to avoid wage compression are more likely to be able to avoid it - or simply to evade it by in fact moving.

Patience is closely related to better exit options. A group that can wait out its challengers will be better able to withstand conflict over adjustment: in the case of firms, those with more financial resources in reserve will be able to outlast those with less. This can be interpreted as simply a re-statement of available exit - waiting is an alternative (exit) option. The same is true of longer time horizons on the part of firms, groups, or individuals - those that discount the future less will be more patient, and have more and better alternatives, hence greater bargaining power. This may help explain, both in the United States and in Europe, why debtors typically lost out to creditors. Whether they were heavily mortgaged households or sovereign governments, debtors were in no position to wait out creditors in negotiations. ${ }^{11}$

One interesting aspect of bargaining over adjustment, particularly relevant in recent debt crises, is inter-generational. In many countries, one of the principal divisions is between young and old; this cleavage is particularly prominent in Europe. Older European citizens, especially in debtor nations, are more likely to be homeowners or others with foreign-currency liabilities, and are thus more likely to be harmed by a nominal depreciation. They are also likely to have greater job security, and to be less

\footnotetext{
${ }^{11}$ Nunez and Rosenthal 2004 analyze the political economy of pro-creditor bankruptcy "reform" in the United States.
} 
affected by high unemployment. Younger citizens, on the other hand, are much more likely to be unemployed, and less likely to be concerned about their assets or liabilities. At the same time, younger Europeans are likely to be more impatient, especially if they are unemployed with few job prospects, which reduces their bargaining power. On the other hand, younger Europeans are also more likely to exit, as migration has become relatively easy within the European Union. Other things equal, this might increase their bargaining power - but it is not clear that politicians care much about the exit of the young. Inasmuch as inter-generational redistribution is of great and increasing importance in all developed societies, it would be well worth exploring the political economy of generational interests and related bargaining influence.

The availability of other alternatives to the status quo - exit, waiting, procrastinating - generally increases the political power of those involved in battles over adjustment. To be sure, the definition of alternatives can be endlessly flexible in the political sphere: exit could mean fomenting a coup, or creating a new political party, or withdrawing capital. ${ }^{12}$ In any case, focusing on the choices available to the protagonists in domestic political battles over adjustment and rebalancing helps clarify the analysis of who is likely to predominate in such battles.

\footnotetext{
${ }^{12}$ Oatley 2004 describes the sometimes contradictory impact of regime type, which exhibits similar complexity; while he does not make the connection to exit explicit, it could well be incorporated into his argument. See also Spolaore 2004.
} 
The domestic and international political economy of adjustment are closely linked. Domestic political considerations often constrain international negotiations, restricting bargaining positions in ways that can make compromise difficult. In the case of the crisis of the Bretton Woods monetary order, for example, many feasible settlements could be imagined, involving some adjustment by both the European surplus nations and the United States. But American domestic politics ruled out adjustment in the deficit country, at least in the view of the Nixon Administration, and the U.S. held the whip hand in the relationship; the collapse of Bretton Woods was, in this sense, almost entirely the result of the domestic politics of adjustment in the United States. In the Eurozone crisis, many observers anticipated that negotiations between debtors and creditors would, as is almost always the case, lead to some debt restructuring. However, it would appear that domestic political constraints in the creditor countries, Germany in particular, may have ruled out concessions of this type. And because in this case it was the surplus countries that held the whip hand, no compromise was forthcoming.

We can go a long way toward understanding the factors that affect the domestic and international political economy of adjustment by analyzing how adjustment measures would affect socio-economic interests, and how their characteristics and those of national and international political institutions affect relative bargaining influence. This is abstract and general, of course, and its value depends on specific applications; 
but at least it gives analysts a framework to work with. However, all this leaves to one side a crucially important question, alluded to earlier in the context of international adjustment problems: why is adjustment so commonly delayed, to the detriment of all concerned?

\section{Explaining delayed adjustment}

It is easy to understand that there are important conflicts of interest in the adjustment process. Especially in a heavily indebted economy, or one facing a major current account deficit that is difficult to finance, adjustment can - at least in the short run - be a negative-sum game. A contested and controversial outcome of a battle over economic adjustment is a terrible thing that can tear societies apart; but no outcome at all is even worse. In many cases, conflict is prolonged, with no consistent policy resolution. Especially in the case of financial crises, delay can be extremely costly. Bad debts accumulate, dragging the economy further and further down and retarding a possible recovery.

The cost of delay implies that a Pareto improvement is available, inasmuch as a clear resolution to the crisis is better than continued conflict and prolonged uncertainty. ${ }^{13}$ This leads us to shift our attention away from the distributional specifics of the contours of the conflict to a different question: why are some distributional conflicts so much harder to resolve than others? Why, and when, does bargaining break

${ }^{13}$ Bolton and Rosenthal 2002 develop the argument in detail. 
down? What are the factors that might lead the protagonists of such conflict to dig their heels in so hard so to make resolution difficult or impossible? This is as true of the GFC as it has been of previous crises. This much seems obvious from the extraordinary costs Europeans have had to bear for the EU's inability to deal effectively with the Eurozone crisis. Mian and Sufi 2014 make an analogous case for the proposition that the United States paid a massive price for the U.S. government's unwillingness to push aggressively for private debt restructuring, relying instead almost entirely on bailing out the affected financial institutions. ${ }^{14}$ What, then, stands in the way of governments adopting policies that could, in the final analysis, make everyone better off?

This question has typically been asked in terms of understanding the eruption of a war of attrition. Theory and history can tell us a great deal about what might in fact prolong (or shorten) such a war of attrition, both in general and in the case of economic adjustment. We can point to four principal factors. There is a certain amount of overlap among them, and they are not mutually exclusive, but each addresses a somewhat different potential cause of delay.

Patience. While the ability to wait out the other side gives one party greater bargaining power, there are instances in which both sides can be patient. ${ }^{15}$ When each participant recognizes that the loser will pay a stiffer price, and is unsure of how long

${ }_{14}$ They develop and apply their ideas further at http://houseofdebt.org/.

${ }^{15}$ This is the core argument of Alesina and Drazen 1991. 
others can last, the best strategy can be to delay in anticipation that one of the others will "blink" first. Groups that think they may be able to out-wait others have powerful incentives to resist any settlement that is not strongly in their favor. Alesina, Ardagna, and Trebbi (2006) apply the war-of-attrition model empirically, and find evidence in support of it. Governments that are new to office, or that are particularly strong - and therefore almost certainly better able to force through a settlement - are more likely to do so, using their position to end the war of attrition quickly. But it is common for governments to confront powerful actors - opposition parties, interest groups, public employees - that have both the resources and the time to wait out their opponents. Uncertainty. When economic actors are unsure as to what the impact of an adjustment policy will be on them, they may have reasons to avoid the implementation of the policy. Fernandez and Rodrik 1991 present a model in which adjustment is welfare-improving, but large numbers of citizens are unsure as to whether they will end up on the winning or losing side of the process. This gives the potential losers a strong bias in favor of the status quo, in which at least they will not be seriously harmed - and this can impart a powerful status quo bias to the political process more generally. While Fernandez and Rodrik apply the model to trade liberalization, it is easy to see how a 
leap into the unknown of a major stabilization program could induce delay on the part of major groups that believed that they could end up losing a lot in the process. ${ }^{16}$ Asymmetric information. One of the forces that can make a war of attrition better than the alternatives is the absence of reliable information on the true preferences, resolve, or resources of opponents. ${ }^{17}$ If one party in the conflict is unsure about how hard the other is willing to fight, then prolonging the bargaining is one way of testing the waters. In this setting, delay is a potentially valuable strategy in pursuit of information revelation, in particular about the true intentions and power of other parties to the negotiation. ${ }^{18}$ Strategically valuable or no, asymmetric information can contribute to serious delays in arriving at a negotiated settlement that is, in the final analysis, in the best interests of all parties.

Commitment problems. It is almost certainly the case that failures to arrive at an adjustment policy are Pareto sub-optimal; however, achieving a Pareto improvement

${ }^{16}$ Ciccone 2004 develops a variant of the argument; Labán and Sturzenegger 1994 revise it to apply in particular to ending high inflations

${ }^{17}$ Adepts of International Relations will note in this and the next the hints of the "bargaining theory of war," as in Fearon 1995 and Reiter 2003 - which is typically applied to actual military conflict. But the approach is just as relevant to (non-military) wars of attrition.

${ }^{18}$ The process is known in the literature on military conflict as "conflict bargaining." 
can be difficult if the commitments made by the various actors are not credible. ${ }^{19}$ Put differently, most Pareto improvements - including in the adjustment process - involve some measure of compensation for those who would be losers in its absence. But if those who need to be compensated do not believe that the promises made to them will be carried out, they have little or no incentive to go along with the bargain. And all involved are well aware of the fact that promises made in the process of negotiating over a major adjustment package are not time-consistent. Features of social relations, or of political institutions, that make commitments more or less credible, can be expected to affect the ease or difficulty with which compromises to settle adjustment-related disputes are reached. ${ }^{20}$

Each of these considerations suggests comparative statics drawn from national socio-economic and political conditions, and the respective literature on them is replete with illustrations. Examples, or at least working hypotheses, are relatively easy to come by. Strong governments unlikely to be removed from office should be better able make

${ }^{19}$ This is related to the supposition of a so-called "political Coase theorem," as in Acemoglu 2003.

${ }^{20}$ As above, an argument could also be made about the "public relations" of a crisis: if American homeowners had been able to convince the public that bailing them out was as important to the economy as bailing out American banks, the policy response to the GFC might have been different. Again, see Mian and Sufi 2014. 
credible commitments, hence quicker to arrive at agreement. Left governments are likely to be able to make more credible commitments to labor, so if this would otherwise be an obstacle they should be more successful in the adjustment process (which may explain why so many successful stabilization and adjustment programs in Latin America are under the auspices of Left governments). The more information parties have about each other's preferences and resources, the more quickly they should be able to arrive at a compromise.

Similar considerations should also apply internationally. The persistence of drawn-out conflicts over adjustments - such as the prolonged quagmire involving Latin American foreign debts in the 1980s - is due to some or all of these factors. In the context of the Eurozone conflict, two considerations appear to have been fundamental, at least as a first approximation. The first is that neither side's commitments were credible to the other. The debtors' promises to adjust were not believed by the creditors, and the creditors' promises to restore normal capital flows were not believed by the debtors. The second is that the creditors, and in particular Germany, seemed quite willing to wait as long as necessary to prevail. This helps explain both why the conflict was so drawn out, and why it tended to be resolved in favor of the creditors.

\section{Conclusion}

It is common for analysts to invoke "politics" to explain the proliferation of conflict, delay, and policy twists and turns as societies deal with the aftermath of debt 
or payments crises. We can do better than to appeal to so vague a putative explanation. There are reasons why people, groups, parties, and countries fight so hard, and so long, to affect the nature of adjustment policies. And there are reasons why the fighting is so often inconclusive, drawn-out, and eventually counter-productive. The implications of the analysis here is perhaps depressing, inasmuch as it demonstrates that there are powerful forces that can lead rational actors to drive their societies toward very undesirable outcomes. In this sense, political economy may well be the truly dismal science. And to be sure, Europe in the aftermath of the Eurozone crisis has given us many, varied, and vivid examples of just how many things can go so wrong. Nonetheless, as always, understanding the sources of policy disasters is the first, necessary, step to avoiding them. 


\section{References}

Acemoglu, Daron. 2003. Why not a Political Coase Theorem? Social Conflict,

Commitment, and Politics. Journal of Comparative Economics 31, No. 4.

Alesina, Alberto and Allan Drazen. 1991. Why are Stabilizations Delayed? American

Economic Review 81, nº 5 (December), pp. 1170-1188.

Bolton, Patrick and Howard Rosenthal. 2002. Political Intervention in Debt Contracts. Journal of Political Economy 110 (October), pages 1103-34.

Ciccone, Antonio. 2004. Resistance to Reform: Status Quo Bias in the Presence of Individual-Specific Uncertainty: Comment. American Economic Review 94, No. 3 (June), pages 785-795.

Cline, William R. 1995. International Debt Reexamined. Washington: Institute for International Economics.

Eichengreen, Barry. 1992. Golden Fetters: The Gold Standard and the Great Depression 19191939. New York: Oxford University Press. 
Jack Ewing. 2013. In Germany, Little Appetite to Change Troubled Banks. New York Times August 9.

Fearon, James. 1995. Rationalist Explanations for War. International Organization, Vol.

49, No. 3 (Summer), pp. 379-414;

Fernandez, Raquel and Dani Rodrik. 1991. Resistance to Reform: Status Quo Bias in the Presence of Individual-Specific Uncertainty. American Economic Review 81, $\mathrm{n}^{\circ} 5$ (December), pp. 1146-1155.

Frieden, Jeffry, Michael Pettis, Dani Rodrik, and Ernesto Zedillo. 2012. After the Fall: The Future of Global Cooperation Geneva Report 14. London: Center for Economic Policy Research.

Labán, Raúl and Federico Sturzenegger. 1994. Distributional Conflict, Financial Adaptation and Delayed Stabilizations. Economics \& Politics, 6, No. 3 (November) pages 257-278. 
Mian, Atif and Amir Sufi. 2014. House of Debt: How They (and You) Caused the Great Recession, and How We Can Prevent It from Happening Again. Chicago: University of Chicago Press.

Mian, Atif, Amir Sufi, and Francesco Trebbi. 2010. The Political Economy of the US Mortgage Default Crisis. American Economic Review 100, No. 5 (December), pages 19671998.

Mian, Atif, Amir Sufi, and Francesco Trebbi. 2014a. Resolving Debt Overhang: Political Constraints in the Aftermath of Financial Crises. American Economic Journal: Macroeconomics 6, No. 2 (April), pages 1-28.

Mian, Atif, Amir Sufi, and Francesco Trebbi. 2014b. Foreclosures, House Prices, and the Real Economy. Working paper.

Nunez, Stephen and Howard Rosenthal. 2004. Bankruptcy "Reform" in Congress:

Creditors, Committees, Ideology, and Floor Voting in the Legislative Process. Journal of Law, Economics, and Organization, 20, No. 2 (Fall), pages 527- 557. 
Oatley, Thomas. 2004. Why is Stabilization Sometimes Delayed? Re-evaluating the Regime Type Hypothesis. Comparative Political Studies 37 (April), pages 286-312.

Pepinsky, Thomas. 2014. Financial Crises and the Politics of Adjustment and Reform. In Research Handbook of International Monetary Relations, Ed. Thomas Oatley and William K. Winecoff. Cheltenham: Edward Alger Publishing.

Reinhart, Carmen and Kenneth Rogoff. 2009. This Time is Different: Eight Centuries of Financial Folly. New York: Princeton University Press.

Reinhart, Carmen M. and Kenneth S. Rogoff. 2014. Recovery from Financial Crises: Evidence from 100 Episodes. NBER Working Paper 19823.

Reiter, Dan. 2003. Exploring the Bargaining Model of War. Perspectives on Politics 1, 1 (March), pages 27-43.

Rodrik, Dani. 2014. When Ideas Trump Interests: Preferences, World Views, and Policy Innovations. Journal of Economic Perspectives 28, No. 1 (Winter), pages 189-208. 
Rubinstein, Ariel. 1982. Perfect Equilibrium in a Bargaining Model. Econometrica 50, No.

1 (January), pages 97-109.

Simmons, Beth. 1994. Who Adjusts? Domestic Sources of Foreign Economic Policy during the Interwar Years. Princeton: Princeton University Press.

Spolaore, Enrico. 2004. Adjustments in Different Government Systems. Economics and

Politics 16, No. 2 (July), pages 117-146.

Sturzenegger, Federico and Jeromin Zettelmeyer. 2006. Debt Defaults and Lessons from a Decade of Crisis. Cambridge: MIT Press.

Walter, Stefanie. 2008. A New Approach for Determining Exchange-Rate Level Preferences. International Organization 62(3), pages 405-38.

Walter, Stefanie. 2013. Financial Crises and the Politics of Macroeconomic Adjustments. Cambridge: Cambridge University Press. 